\title{
Effects of an extremely dry winter on net ecosystem carbon exchange and tree phenology at a cork oak woodland
}

\author{
Filipe Costa-e-Silva ${ }^{\mathrm{a}, *}$, Alexandra C. Correia ${ }^{\mathrm{a}}$, Arndt Piayda $^{\mathrm{b}}$, Maren Dubbert ${ }^{\mathrm{c}}$, \\ Corinna Rebmann ${ }^{\mathrm{b}}$, Matthias Cuntz ${ }^{\mathrm{b}}$, Christiane Werner $^{\mathrm{c}}$, Jorge Soares David ${ }^{\mathrm{a}}$, \\ João Santos Pereira ${ }^{a}$ \\ a CEF, Instituto Superior de Agronomia, Universidade de Lisboa, Tapada da Ajuda, 1349-017 Lisboa, Portugal \\ ${ }^{\mathrm{b}}$ Deptartment Computational Hydrosystems, UFZ Helmholtz Centre for Environmental Research, Permoserstraße 15, 04318 Leipzig, Germany \\ ${ }^{\mathrm{c}}$ Agroecosystem Research, BayCeer, University of Bayreuth Universitätsstraße 30, 95447 Bayreuth, Germany
}

\section{A R T I C L E I N F O}

\section{Article history:}

Received 2 June 2014

Received in revised form 12 January 2015

Accepted 29 January 2015

Available online 6 February 2015

\section{Keywords:}

$\mathrm{CO}_{2}$ fluxes

Evergreen oak

Leaf area index

Mediterranean woodland

Quercus suber $\mathrm{L}$.

Tree diameter increment

\begin{abstract}
A B S T R A C T
In seasonally dry climates, such as the Mediterranean, lack of rainfall in the usually wet winter may originate severe droughts which are a main cause of inter-annual variation in carbon sequestration. Leaf phenology variability may alter the seasonal pattern of photosynthetic uptake, which in turn is determined by leaf gas exchange limitations. The current study is based on the monitoring of an extremely dry winter in an evergreen cork oak woodland under the Mediterranean climate of central Portugal. Results are focused on net ecosystem $\mathrm{CO}_{2}$ exchange (NEE), phenology and tree growth measurements during two contrasting years: 2011, a wet year with a typical summer drought pattern and 2012, with an extremely unusual dry winter (only $10 \mathrm{~mm}$ of total rainfall) that exacerbated the following summer drought effects. Main aims of this study were to assess the effects of an extreme dry winter in (1) annual and seasonal net ecosystem $\mathrm{CO}_{2}$ exchange, and in (2) cork oak phenology. The dry year 2012 was marked by a $45 \%$ lower carbon sequestration ( $-214 \mathrm{vs}$. $-388 \mathrm{~g} \mathrm{C} \mathrm{m}^{-2}$ year $^{-1}$ ) and a $63 \%$ lower annual tree diameter growth but only a $9 \%$ lower leaf area index compared to the wet year 2011. A significant reduction of $15 \%$ in yearly carbon sequestration was associated with leaf phenological events of canopy renewal in the early spring. In contrast to male flower production, fruit setting was severely depressed by water stress with a $54 \%$ decrease during the dry year. Our results suggest that leaf growth and leaf area maintenance are resilient ecophysiological processes under winter drought and are a priority carbon sink for photoassimilates in contrast to tree diameter growth. Thus, carbon sequestration reductions under low water availabilities in cork oak woodland should be ascribed to stomatal regulation or photosynthetic limitations and to a lesser extent to leaf area reductions.
\end{abstract}

(C) 2015 Elsevier B.V. All rights reserved.

\section{Introduction}

Cork oak (Quercus suber L.) open woodlands cover an area of about 2-2.5 million ha in the western Mediterranean (Aronson et al., 2009). These are man-made ecosystems exploited with

Abbreviations: $(\mathrm{C} / \mathrm{N})$, carbon-to-nitrogen ratio; (DBH), diameter at breast height; (DOY), day of year; (ET), ecosystem evapotranspiration; (GPP), gross primary productivity; (LAI), leaf area index; $\left(\mathrm{LAI}_{\max }\right)$, maximum leaf area index; $\left(\mathrm{LAI}_{\min }\right)$, minimum leaf area index; (LUE), light use efficiency; (NEE), net ecosystem exchange; (PAR), photosynthetically active radiation; (PLC), percentage loss in hydraulic conductivity; $\left(\Psi_{\mathrm{md}}\right)$, midday leaf water potential; $\left(\Psi_{\mathrm{pd}}\right)$, predawn leaf water potential; $\left(R_{\text {eco }}\right)$, ecosystem respiration; (se), standard error of the mean; (SLA), specific leaf area; (SWC), soil water content; $\left(u^{*}\right)$, friction velocity; $\left(\mathrm{VPD}_{\max }\right)$, maximum vapor pressure deficit.

* Corresponding author. Tel.: +35121365 3515; fax: +351 213653338 .

E-mail address: filipecs@isa.utl.pt (F. Costa-e-Silva). low-impact agro-forestry, with high biodiversity and conservation value (Bugalho et al., 2011). In Portugal these woodlands cover 0.74 million ha and represent $23 \%$ of all forested area. Cork oak has a significant economic value. It provides $0.7 \%$ of Portugal gross domestic product and supplies $54 \%$ of the worldwide cork production (Evangelista, 2010). Cork is a natural product consisting of continuous annual layers of suberized tissue produced by phellogen, a secondary meristem wrapping the inner bark. Cork wine bottle stoppers is the main product and to obtain commercial grade cork stripping is done traditionally every 9 years. Cork removal can only be safely done when the phellogen cells are actively dividing, in late-spring and early-summer, to prevent injuries to the tree (Costa et al., 2003).

Cork oak is well adapted to the adverse semiarid Mediterranean climate and its ecophysiology has been well studied in the last decades (e.g., Otieno et al., 2007; Pereira et al., 2009; Vaz 
et al., 2010). Adverse conditions result mainly from scarce water resources during a long dry summer season, usually coupled with high temperatures and high radiation. In a seasonal climate such as the Mediterranean, a drought is said to occur when precipitation shortages, often coupled to high evaporative demand, reduce moisture availability for an extended period during the normally wet season (Pereira et al., 2006). Successful adaptations to cope with water stress range from an efficient root and water transport system (David et al., 2007; Kurz-Besson et al., 2006) to a tight stomatal regulation at the leaf level, restricting water loss while limiting the rate of $\mathrm{CO}_{2}$ assimilation (Otieno et al., 2007; Pinto et al., 2012; Vaz et al., 2010). Nevertheless, and despite being considered drought resilient, a succession of dry years or severe stress events may lead the trees to surpass their tolerance thresholds and result in episodes of tree mortality (Pereira et al., 2009). In addition, the Mediterranean region is among the most sensitive regions to climate change, with all recent climate projections forecasting more frequent extreme events (Reichstein et al., 2013), such as heat waves and severe droughts (e.g., Giorgi and Lionello, 2008).

In Mediterranean regions phenological patterns are strongly influenced by a marked climatic seasonality and species evolved to synchronize maximum vegetative activity to the most favorable periods of the year (Misson et al., 2011; Pinto et al., 2011; Richardson et al., 2010). Timing of budburst and growing season length can directly impact net ecosystem carbon uptake (Baldocchi, 2008; Richardson et al., 2010) and leaf age effects on canopy carbon uptake (Niinemets et al., 2005). However, an earlier spring onset can be associated with either enhanced or decreased productivity later in the growing season (e.g., depending on interactions with water availability), and thus, early-season gains can be offset by sustained late-season reductions in physiological activity (Richardson et al., 2010). Therefore, the evaluation of interactions between climate change effects, phenological events and net ecosystem exchange requires specific ecosystem scale analysis.

In the case of Mediterranean forests, droughts are a main source of interanual variation in carbon sequestration as they

Table 1

General soil, climate, and vegetation characteristics in 2011 and 2012. Values are means \pm se.

\begin{tabular}{|c|c|c|c|}
\hline Characteristic & 2011 & 2012 & Units \\
\hline \multicolumn{4}{|l|}{ Soil } \\
\hline Organic matter & $3.2 \pm 0.2$ & & $(\%)$ \\
\hline $\mathrm{C} / \mathrm{N}$ & $19.3 \pm 1.4$ & & \\
\hline Carbon stock (up to $60 \mathrm{~cm}$ ) & 62.2 & & $\left(\mathrm{tCha} \mathrm{C}^{-1}\right)$ \\
\hline \multicolumn{4}{|l|}{ Climate } \\
\hline Mean temperature & 16.1 & 15.2 & $\left({ }^{\circ} \mathrm{C}\right)$ \\
\hline PAR & 13033 & 13606 & $\left(\mathrm{~mol} \mathrm{~m}^{-2}\right)$ \\
\hline Reference evapotranspiration & 1461 & 1469 & $(\mathrm{~mm})$ \\
\hline Total precipitation & 800 & 469 & $(\mathrm{~mm})$ \\
\hline Total evapotranspiration (ET) ${ }^{\mathrm{a}}$ & 454 & 340 & $(\mathrm{~mm})$ \\
\hline winter & $75(293)$ & $103(10)$ & $(\mathrm{mm})$ \\
\hline spring & $161(217)$ & $106(113)$ & $(\mathrm{mm})$ \\
\hline summer & $148(26)$ & $84(33)$ & $(\mathrm{mm})$ \\
\hline autumn & $69(264)$ & $47(313)$ & $(\mathrm{mm})$ \\
\hline \multicolumn{4}{|l|}{ Vegetation } \\
\hline Tree density & 177 & & $\left(\right.$ trees ha $\left.^{-1}\right)$ \\
\hline Tree crown cover & 50 & & (\%) \\
\hline Tree height & $7.9 \pm 0.26$ & & $(\mathrm{~m})$ \\
\hline Tree $\mathrm{DBH}^{\mathrm{b}}$ & $24.7 \pm 1.2$ & & $(\mathrm{~cm})$ \\
\hline Maximum $\mathrm{LAI}^{\mathrm{C}}$ & 1.15 & 1.05 & $\left(\mathrm{~m}^{2} \mathrm{~m}^{-2}\right)$ \\
\hline Total tree C stock & 33.7 & & $\left(\mathrm{tCha} \mathrm{C}^{-1}\right)$ \\
\hline Shrubs above-ground C stock & $0.34 \pm 0.10$ & $0.51 \pm 0.18$ & $\left(\mathrm{tCha} \mathrm{C}^{-1}\right)$ \\
\hline Grasses above-ground C stock & $0.32 \pm 0.05$ & $0.10 \pm 0.02$ & $\left(\mathrm{tCha} \mathrm{C}^{-1}\right)$ \\
\hline
\end{tabular}

a Numbers in brackets are seasonal precipitation.

b DBH, diameter at breast height.

c LAI, leaf area index. strongly reduce gross primary productivity as well as net ecosystem exchange (NEE) (Pereira et al., 2007). Under drought conditions, leaf phenology may play an important role in controlling the temporal dynamics of tree crown productivity and NEE, not only in deciduous forests but also in evergreen species with a short leaf life-span. In the latter (as it is the case of cork oak), senescence and development of a new canopy in spring may control, to a large extent, the patterns of photosynthetic uptake in the following growing season. We hypothesized that a winter drought is liable to impose limitations on leaf phenophase progression (e.g., budburst and leaf expansion) which might exacerbate summer drought effects.

The current study is based on the monitoring of an extremely dry winter (only $10 \mathrm{~mm}$ of total rainfall) in a certified evergreen cork oak woodland under the Mediterranean climate of central Portugal. Results are centered on ecosystem $\mathrm{CO}_{2}$ fluxes (micrometeorological method, eddy-covariance technique), phenology and tree growth measurements during two contrasting years: 2011, a wet year with a typical summer drought pattern and 2012, with an extreme dry winter that exacerbated the following summer drought effects. Main aims of this study were to assess the effects of an extreme dry winter in (1) annual and seasonal net ecosystem $\mathrm{CO}_{2}$ exchange (NEE), and in (2) cork oak phenological events (e.g., budburst, tree growth, and fruit setting).

\section{Material and methods}

\subsection{Site description}

In 2009 an experimental site was established at Herdade da Machoqueira located in Central Portugal $\left(39^{\circ} 08^{\prime} 18.29^{\prime \prime} \mathrm{N}\right.$, $\left.8^{\circ} 19^{\prime} 57.68^{\prime \prime} \mathrm{W}\right)$. Vegetation consists of a ca. 50 -yr-old cork oak $(Q$. suber) open woodland with an understory of semi-deciduous shrub species (e.g., Cistus sp. and Ulex sp.) and native grassland. This understory vegetation is highly seasonal with growth beginning after the autumn rains and lasting until June when grassland diesout and shrubs enter a quiescent period. Maximum leaf area index measured in 2011 in the understory vegetation was 0.38 and 0.45 for shrubs and grassland, respectively (Correia et al., 2014). The climate is Mediterranean, with wet and mild winters and dry and hot summers. Average annual precipitation is $680 \pm 210 \mathrm{~mm}$ and mean annual temperature is $15.9^{\circ} \mathrm{C}$ (period $1955-2007$, Inst. de Meteorologia, Lisbon). The soil is a cambisol (FAO), with $81 \%$ sand, $5 \%$ clay, and $14 \%$ silt, with roots mainly in the upper horizons (ca. $0-40-\mathrm{cm}$ depth) and some sinker roots taking water from deeper soil horizons and subsoil. From observations from an underground tank the water table is estimated to vary between 3 and $5 \mathrm{~m}$ depth. Other general site characteristics are described in Table 1 for the studied period.

\subsection{Environmental parameters}

Meteorological data on rainfall (ARG100; Environmental Measurements Ltd., Gateshead, UK), photosynthetically active radiation (BF2; Delta-T Devices Ltd., Cambridge, UK), air humidity and temperature (CS215; Campbell Scientific, Inc., Logan, UT, US) were collected continuously in 30-min time intervals (CR10X; Campbell Scientific, Inc., Logan, UT, US). Soil volumetric water content was measured up to 40 -cm depth $(2,10,20,30$, and $40 \mathrm{~cm})$ with dielectric soil moisture sensors in four different places (EC5; Decagon Devices, Inc., Pullman, WA, US). These measurements were automatically collected in a datalogger (Em50; Decagon Devices, Inc., Pullman, WA, US) as 30-min averages. Reference evapotranspiration was determined according to the FAO Penman-Monteith method (Allen et al., 1998). 


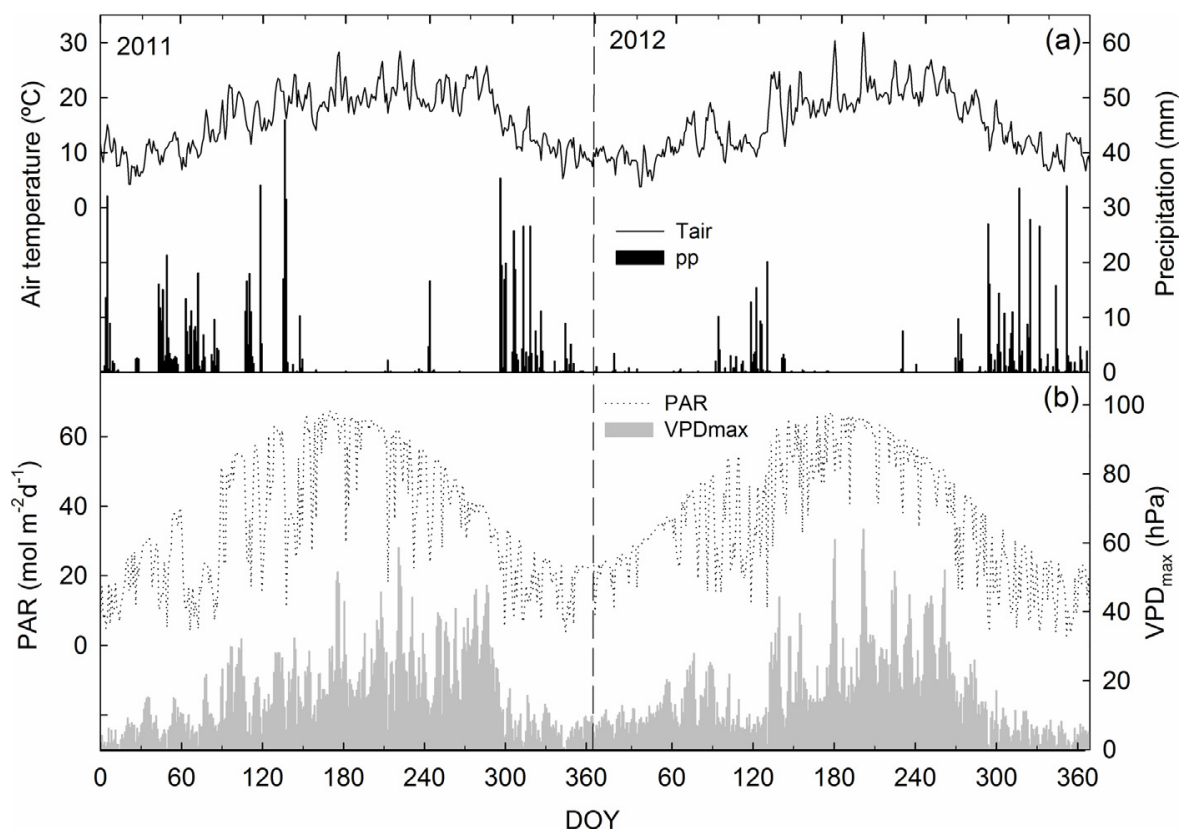

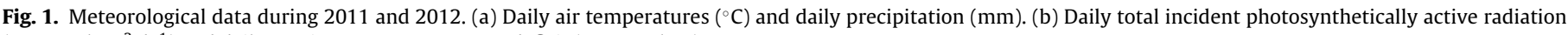
(PAR, mol $\mathrm{m}^{-2} \mathrm{~d}^{-1}$ ) and daily maximum vapor pressure deficit (VPD $\max , \mathrm{hPa}$ ).

\subsection{Phenological and ecophysiological measurements}

Litter fall was collected by 16 baskets of $1 \mathrm{~m}^{2}$ placed in two transects across the footprint area of eddy flux measurements and sampled every 15 days throughout 2011 and 2012, with separation of leaves, branches, male flowers (catkins), and acorns. Additionally, litter fall was collected in six trees with four baskets each placed at half distance of tree canopy radius. In these same trees, budburst time and individual leaf dimension were registered in a sampled branch per tree (selected in the south of the canopy) to determine the start and duration of the leaf growth period. Tree leaf area index (LAI) was calculated using leaf biomass from litter fall (transects) and species specific leaf area (SLA) following Limousin et al. (2009). Maximum LAI ( LAI $_{\max }$ ) was assumed to be coincident with the end of new leaf growth in that year and was determined by the sum of the area of all leaves shed belonging to the leaf cohort of that year. In each date LAI was determined by subtracting to LAI max the area of all leaves shed until that date. Between budburst and complete leaf expansion LAI increase was determined assuming a linear leaf growth.

Tree height, tree diameter, and tree biomass per hectare was estimated by measuring all tree diameters and heights in a representative plot of $40-\mathrm{m}$ radius. Tree above-ground biomass components (leaves, trunks, and branches) were estimated subsequently using species-specific allometric equations (Paulo and Tomé, 2006).
Tree-stem diameter growth was measured with dendrometer bands $( \pm 0.1 \mathrm{~mm})$ installed in 12 trees with average diameter $33.2 \pm 1.8 \mathrm{~cm}$ at breast height and registered every 15 days throughout 2011 and 2012. Leaf xylem water potential was measured at predawn $\left(\Psi_{\mathrm{pd}}\right)$ and midday $\left(\Psi_{\mathrm{md}}\right)$ with a Scholander-type pressure chamber (PMS Instruments, Corvallis, OR, US) in six trees. Measurements were done in early summer, day of year (DOY) 166 and 171 , and in the peak of the summer drought, DOY 263 and 256 for both 2011 and 2012, respectively.

\subsection{Soil analysis}

Soil samples were taken randomly from three $10-\mathrm{cm}$ depth soil profiles, together with undisturbed soil samples for soil bulk density calculations. Soil organic carbon concentration was determined by the dry combustion method according to the International Organization for Standardization 10,694, using a CNS elemental analyser (Leco CNS-2000, MI, US). Nitrogen concentration was determined by Kjeldahl digestion analysis (Digestion System 40; Kjeltec Auto 1030 Analyser, DEcator, SE). Soil organic carbon content was determined using the method referred in IPCC (2003).

\subsection{Ecosystem flux measurements}

The fluxes of $\mathrm{CO}_{2}$, water vapor and sensible heat were continuously measured (at $23.5 \mathrm{~m}$ above ground) by an eddy-covariance

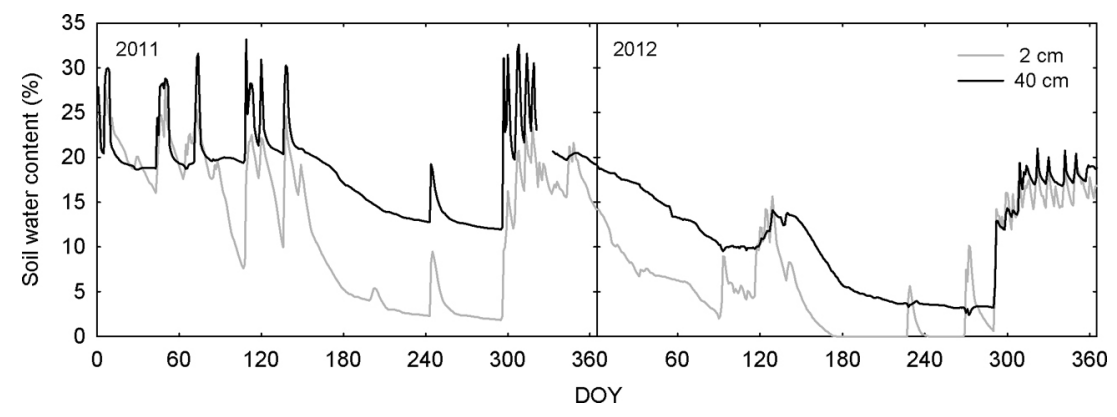

Fig. 2. Daily values of soil water content (\%) at 2 and $40 \mathrm{~cm}$ depth during 2011 and 2012 . 
system installed at the top of a $22 \mathrm{~m}$ high tower. The system consisted of a 3-D sonic anemometer (R3; Gill Instruments Ltd., Lymington, UK) and a closed-path infrared gas analyzer (LI-7000; LI-COR Inc., Lincoln, NE, US), measuring the three components of wind velocity and temperature, and the concentration of water vapor and $\mathrm{CO}_{2}$. The inlet tube of the gas analyzer ( $8 \mathrm{~m}$ long) was attached to one of the anemometer arms and operated with an average flow rate of ca. $8 \mathrm{~L} \mathrm{~min}^{-1}$. The reference cell is flushed with $\mathrm{N}_{2}$, and $\mathrm{CO}_{2}$ and $\mathrm{H}_{2} \mathrm{O}$ calibrations are done every 15 days. Data were continuously acquired on a field laptop with EddyMeas (Meteotools, Jena, DE; Kolle and Rebmann, 2007).

Eddy flux data was treated using the eddy-covariance data acquisition and processing software package EddySoft and selfwritten Python scripts. Fluxes were determined on a half-hourly basis by block-averaging the $20 \mathrm{~Hz}$ data. Time lags between $\mathrm{CO}_{2}$ or $\mathrm{H}_{2} \mathrm{O}$ signals and vertical wind velocity (2.8 and $5.1 \mathrm{~s}$, respectively) were determined through cross correlation analysis following Aubinet et al. (2000). Whenever this cross correlation failed, the dependency on relative humidity was used to determine the lag for the $\mathrm{H}_{2} \mathrm{O}$ signal (Ibrom et al., 2007). High frequency losses were compensated with the use of inductances derived from co-spectrum analysis ( 0.1 and 0.44 for $\mathrm{CO}_{2}$ and $\mathrm{H}_{2} \mathrm{O}$, respectively) (Eugster and Senn, 1995). The sectorial planar fit method was used for the coordinate rotation of wind vectors (Rebmann et al., 2012; Wilczak et al., 2001). Moisture and cross wind correction were applied after Schotanus et al. (1983). The storage term of $\mathrm{CO}_{2}$ was calculated according to Hollinger et al. (1994) and added to the turbulent $\mathrm{CO}_{2}$ flux.

For quality control, flags were determined for every half-hourly flux value including the following tests: $20 \mathrm{~Hz}$ data was scanned for exceeded physical limits, change rates, and variances; a stationarity test was applied to the high frequency data based upon a 50\% deviation criterion (Foken and Wichura, 1996); on a half-hourly basis a friction velocity $\left(u^{*}\right)$ filtering and the integral turbulence characteristics were calculated following Thomas et al. (2002) with a $30 \%$ deviation criterion; a spike detection routine was used based on the absolute median deviation principle (Papale et al., 2006). All quality control tests were summed up in a simplified flag system (Mauder and Foken, 2011). Total data gaps during the whole study period, due to missing and rejected data, were about $42 \%$. Gap filling and flux-partitioning methods proposed by Reichstein et al. (2005) were used to fill data gaps and to separate the net ecosystem exchange (NEE) into gross primary productivity (GPP) and ecosystem respiration $\left(R_{\text {eco }}\right)$.

Fluxes footprints were estimated for both studied years using the ART footprint tool (Neftel et al., 2008). During the two years of observations, the diurnal average footprint ellipse length was $683 \mathrm{~m}$ (51 ha), being the fluxes predominantly originated (average 91\%) from cork oak woodland with high tree density (>100 trees $\mathrm{ha}^{-1}$ ) with an understory of shrub species and grassland. The uncertainties in the annually integrated values of NEE were calculated using the 'daily-differencing' approach, as described by Richardson et al. (2006). The accumulated random errors in measured net $\mathrm{CO}_{2}$ fluxes were \pm 5.4 and $\pm 4.5 \mathrm{~g} \mathrm{C} \mathrm{m}^{-2}$ year $^{-1}$ in 2011 and 2012, respectively. Nevertheless, all estimated NEE annual sums have to be interpreted with some caution due to the effect of systematic errors.

\subsection{Data and statistical analysis}

Light use efficiency (LUE) was calculated as the ratio between daily-integrated gross carbon assimilation (i.e., GPP) and the daily-integrated incident photosynthetically active radiation (PAR), expressed in $\mathrm{mg} \mathrm{C} \mathrm{mol}^{-1}$. Three periods of approximately 15 days each were used in each year to characterize seasonal changes in LUE: maximum rate of leaf fall - coincident with minimum LAI (early spring), peak of leaf growth period - coincident with maximum LAI (early summer) and peak of summer drought stress - coincident with the lowest $\Psi_{\text {pd }}$ (late summer). Mean light use efficiencies in these three periods were calculated using original and high quality gapfilled data and only considering days with similar $\operatorname{PAR}\left(52.9 \pm 1.7 \mathrm{~mol} \mathrm{~m}^{-2} \mathrm{~d}^{-1}\right)$.

To examine differences between variables (e.g., litter fall components and leaf water potential) we used one-way ANOVA. When ANOVA assumptions where not met, namely normal distribution of the data and homogeneity of variances, non-parametric Kruskal-Wallis test was carried out. Analysis were performed using STATISTICA (Version 7, StatSoft, Inc., 2004). Seasonal data comparisons were done considering, e.g., winter corresponding to January + February + March (e.g., 3-months sums of NEE).

\section{Results}

\subsection{Meteorology and soil water availability}

Meteorological conditions in the study period were quite contrasting: 2011, a wet year with a typical summer drought pattern and 2012, with an extremely unusual dry winter that exacerbated the following summer drought effects. The year 2011 was relatively wet with annual rainfall $(800 \mathrm{~mm}) 18 \%$ higher than the long-term average ( $680 \mathrm{~mm})$. Conversely, 2012 was dry: with an annual rainfall $(469 \mathrm{~mm}) 31 \%$ lower than the long-term average (Table 1$)$. In particular, 2012 had an extreme low winter rainfall of only $10 \mathrm{~mm}$ (Fig. 1a), and winter/spring rainfall was 76\% lower than in 2011. Nevertheless, in April and May 2012 a total of $111 \mathrm{~mm}$ of rain was recorded, attenuating the drought effect of the previous period. Although 2012 was a dry year, its annual average temperature was lower than that of 2011 (15.2 vs. $16.1^{\circ} \mathrm{C}$, respectively, Table 1$)$. In particular and remarkably, April 2011 showed an extremely high average temperature $\left(17^{\circ} \mathrm{C}\right)$, whereas 2012 presented an unusually low average temperature $\left(11^{\circ} \mathrm{C}\right)$, both years contrasting with the 50 -year April average of $13.5^{\circ} \mathrm{C}$. Furthermore, the 2011 summer drought extended through October with high temperatures until the onset of autumn rains in November, whereas in 2012 autumn rains started 30 days earlier (Fig. 1a).

Due to a higher quantity of sunny days in the first three months of 2012 total PAR was 57\% higher than in the same period of 2011. Despite the significant lower total rainfall in 2012, the average of daily maximum vapor pressure deficit $\left(\mathrm{VPD}_{\max }\right)$ was only slightly higher in the summer months of 2012 compared to 2011 (28 vs. $25 \mathrm{hPa}$, respectively) (Fig. $1 \mathrm{~b}$ ).

Volumetric soil water content (SWC) followed closely precipitation events and both at 2 and 40-cm depth, SWC in 2012 was noticeably lower than in 2011 (Fig. 2). Differences in SWC during 2012 , compared to 2011, were progressively larger as time progressed: reductions of 29,51 , and $72 \%$ at $40-\mathrm{cm}$ depth in winter ( 21 vs. $15 \%$ SWC), spring ( 21 vs. $10 \%$ SWC) and summer (14 vs. $4 \%$ SWC), respectively. Upon soil rewetting with the autumn rains SWC increased similarly in both years.

\subsection{Ecosystem $\mathrm{CO}_{2}$ fluxes}

Total annual $\mathrm{CO}_{2}$ fluxes clearly showed the effect of the extreme dry winter of 2012 by reducing carbon sequestration: absolute $\mathrm{CO}_{2}$ uptake decreased from -388 in 2011 to $-214 \mathrm{~g} \mathrm{C} \mathrm{m}^{-2}$ year $^{-1}$ in 2012 (Fig. 3c). However, there were noticeable seasonal differences in NEE between years. Even though 2012 started with three very dry months, absolute $\mathrm{CO}_{2}$ uptake in this 90-day period was significantly higher than in the same period of 2011 (-111 vs. $-56 \mathrm{~g} \mathrm{C} \mathrm{m}^{-2}$, respectively) (Fig. 3c). Following this period, after DOY 90 of 2011 there was a noticeable decrease in absolute NEE daily values, going from an average of -28 in March to $-15 \mathrm{~g} \mathrm{C} \mathrm{m}^{-2}$ in April in spite of the more favorable climatic growing conditions 


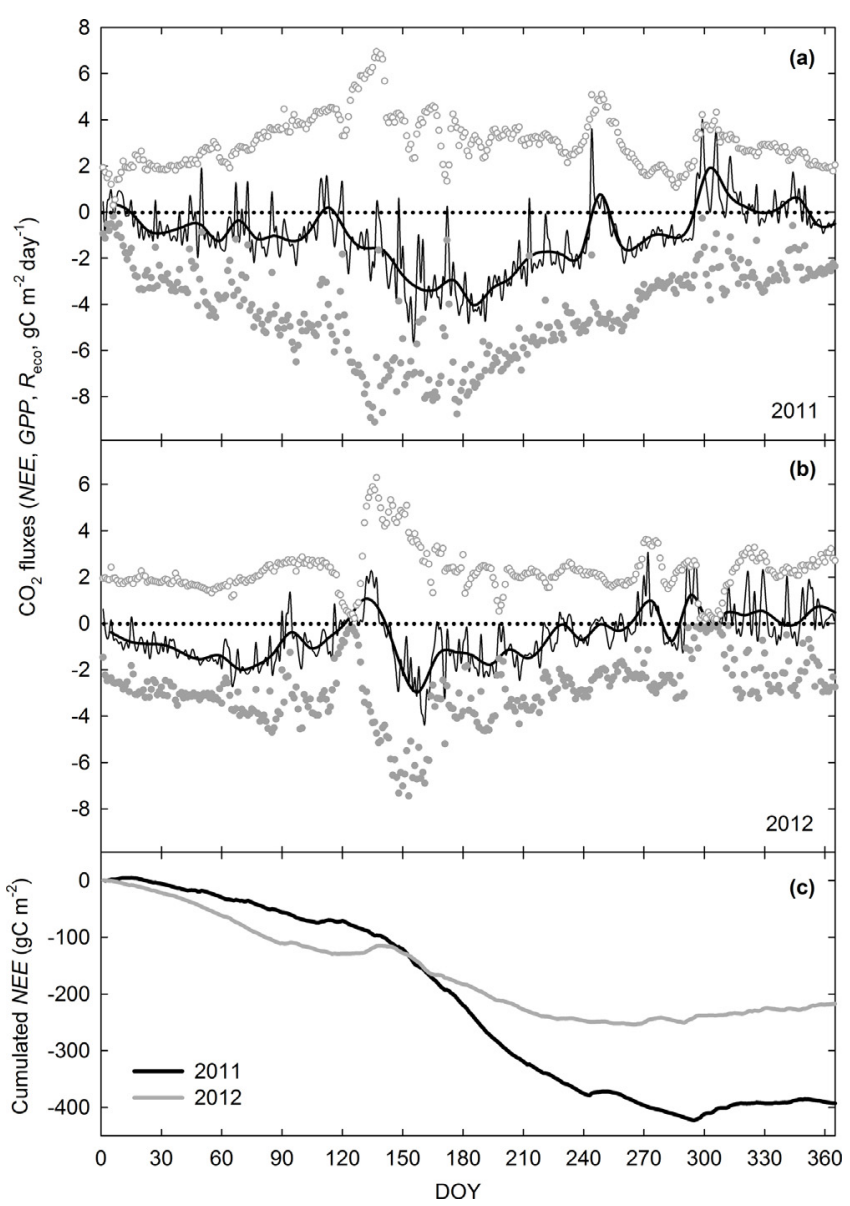

Fig. 3. Daily values of gross primary productivity (GPP, grey closed circles), ecosystem respiration ( $R_{\text {eco, }}$, grey open circles) and net ecosystem exchange (NEE, black line) during 2011 (a), 2012 (b) and cumulated NEE (c). Negative values represent carbon sequestration in the ecosystem while positive values represent carbon emissions to the atmosphere. The strong black line in panels (a) and (b) stands for a 10-day running average.

of air temperature and PAR in the latter. Similarly, an even more striking decrease in absolute NEE occurred in 2012 after DOY 115 ( -18 to $-1 \mathrm{gC} \mathrm{m}^{-2}$, from April to May, respectively). In both years, this low carbon sequestration was the result of a decrease in GPP and smaller increases in $R_{\text {eco }}$ (Fig. $3 \mathrm{a}$ and b). In fact, in a comparison between the period before the onset of leaf fall and the period coincident with the highest leaf fall, absolute GPP decreased 9 and 35\%, whereas $R_{\text {eco }}$ increased 5 and 11\% in 2011 and 2012, respectively. Considering the average decrease in $C$ uptake in this leaf fall period of canopy renewal (ca. 30-day), the reduction in carbon sequestration represents on average a $15 \%$ reduction of yearly NEE. It is worth mentioning that the observed peak in $R_{\text {eco }}$ around DOY 135 in 2012 occurs much later than the first precipitation events (25 mm in DOY 90-105), and thus, should not be related with a soil respiration pulse (due to soil heterotrophic respiration) after the 3-month winter dry period. Interestingly, on an annual timeframe, the ecosystem is occasionally a source of carbon to the atmosphere, during these short spring periods and in the end of the year after the onset of autumn rains (Fig. $3 a$ and $b$ ).

After these low carbon sequestration spring periods, absolute GPP gradually increased, reaching maximums of 9.1 and $7.5 \mathrm{~g} \mathrm{C} \mathrm{m}^{-2}$ day $^{-1}$ in DOY 136 and 153 in 2011 and 2012, respectively. When comparing $\mathrm{CO}_{2}$ fluxes along the growing season (April-September) in both years, there was a $45 \%$ lower absolute GPP in the dry 2012 compared to 2011 (574 and $1039 \mathrm{~g} \mathrm{C} \mathrm{m}^{-2}$, respectively) in parallel with a $35 \%$ lower $R_{\mathrm{eco}}\left(435\right.$ and $671 \mathrm{~g} \mathrm{C} \mathrm{m}^{-2}$, respectively). Nevertheless, while in 2011 high values of carbon assimilation were maintained until DOY 190 to only subsequently decrease gradually until the end of summer, in the dry 2012 the decrease in GPP occurs abruptly after DOY 160 (Fig. 3a and b). In fact, from July to September 2012 a $66 \%$ decrease in carbon sequestration contrasts with the same period of 2011 (NEE of -61 and $-178 \mathrm{~g} \mathrm{C} \mathrm{m}^{-2}$, respectively).

Around DOY 240 in 2011 an isolated $22 \mathrm{~mm}$ rain event caused an ecosystem $\mathrm{CO}_{2}$ efflux to the atmosphere mostly due to a soil respiration pulse as a consequence of soil rehydration (Fig. 3a). With the onset of autumn rains the ecosystem turned into a permanent source of carbon to the atmosphere with a higher $R_{\text {eco }}$ than GPP throughout autumn/early winter.

\subsection{Light use efficiency}

The main seasonal variation and interanual differences in LUE can be perceived in Fig. 4. In the early spring, when leaf fall was more intense and tree LAI was in its minimum, LUE was significantly higher in 2011 than in 2012 (93 \pm 6 vs. $69 \pm 9 \mathrm{mg} \mathrm{C} \mathrm{mol}^{-1}$, respectively). This difference was the result of higher LAI in 2011 in comparison to 2012 (Fig. 6) in this tree canopy phenophase. In late spring/early summer, LUE showed the highest values in both years in accordance with maximum LAI due to canopy renewal. Differences in LUE became highlighted in late summer both among seasons and between years. Whereas, in 2011 LUE was maintained relatively high during summer drought stress it showed the lowest annual values in 2012 ( $90 \pm 3 \mathrm{vs}$. $38 \pm 3 \mathrm{mg} \mathrm{C} \mathrm{mol}^{-1}$, respectively). When comparing the reduction of LUE from the peak of the growing season (early summer) to the peak of drought stress, carbon assimilation was much less affected in 2011 than in 2012 (on average $-40 \%$ vs. $-72 \%$, respectively). During winter and autumn seasons LUE showed no differences between years with relatively high values (92 $\pm 5 \mathrm{mg} \mathrm{C} \mathrm{mol}^{-1}$, on average) as a result of much higher decreases in PAR than in GPP.

\subsection{Tree leaf water potential}

Tree leaf water potential measured in early summer of both years indicated no signs of water deficits as shown by the high $\Psi_{\mathrm{pd}}$ values and low $\Psi_{\text {md }}$ (Table 2). However, by late summer 2012 a clear water stress had developed with $\Psi_{\text {pd }}$ reaching $-2.2 \mathrm{MPa}$, and its small difference to $\Psi_{\text {md }}$ suggests a high stomatal closure. Conversely, in 2011, the higher water availability in summer is apparent

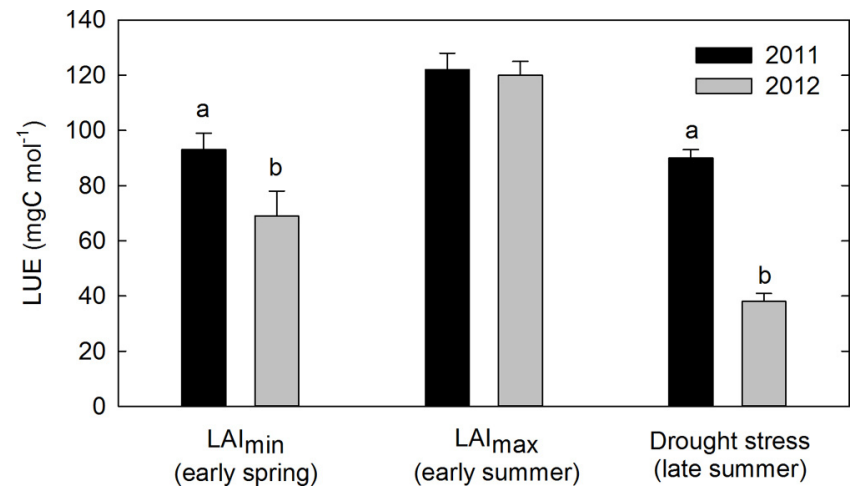

Fig. 4. Light use efficiency (LUE, $\mathrm{mg} \mathrm{C} \mathrm{mol}{ }^{-1}$ ) over the seasons of 2011 and 2012 Mean LUE was calculated for early spring (2011: DOY 94-107 and 2012: DOY 125-144), early summer (2011: DOY 164-181 and 2012: DOY 151-163) and late summer (2011: DOY 240-259 and 2012: DOY 245-261) in days with similar PAR $\left(52.9 \pm 1.7 \mathrm{~mol} \mathrm{~m}^{-2} \mathrm{~d}^{-1}, n=10-15\right)$. Values are means \pm se. Different letters represent statistical significance at $P<0.05$, no letters means no differences. 
Table 2

Predawn $\left(\Psi_{\mathrm{pd}}\right)$ and midday ( $\left.\Psi_{\mathrm{md}}\right)$ tree leaf water potentials (MPa, $n=6$ ) measured during 2011 and 2012 in early and late summer. Values are means \pm se. Different letters represent statistical significance at $P<0.05$, no letters means no differences.

\begin{tabular}{|c|c|c|c|}
\hline \multirow{2}{*}{$\begin{array}{l}\text { Leaf water } \\
\text { potential } \\
(\mathrm{MPa})\end{array}$} & Early summer & \multicolumn{2}{|l|}{ Late summer } \\
\hline & $\Psi_{\mathrm{md}}$ & $\Psi_{\mathrm{pd}}$ & $\Psi_{\mathrm{m}}$ \\
\hline 2011 & $-0.9 \pm 0.1 \mathrm{a}-1.7 \pm 0.1$ & $-1.3 \pm 0.1 \mathrm{a}$ & $-2.2 \pm 0.1$ \\
\hline 2012 & $-0.4 \pm 0.02 b-1.6 \pm 0.2$ & $-2.2 \pm 0.2 \mathrm{~b}$ & $-2.4 \pm 0.2$ \\
\hline
\end{tabular}

Measurements: DOY 166 and 263 (2011) and DOY 171 and 256 (2012).

Table 3

Total annual litter fall and litter fall components during 2011 and 2012 in $\mathrm{g} \mathrm{m}^{-2}$ year $^{-1}$. Values are means \pm se $(n=6)$. Different letters represent statistical significance at $P<\mathrm{n} 0.05$, no letters means no differences.

\begin{tabular}{lcc}
\hline Litter component & 2011 & 2012 \\
\hline Leaves & $190 \pm 10 \mathrm{a}$ & $151 \pm 13 \mathrm{~b}$ \\
Branches & $47 \pm 9$ & $38 \pm 9$ \\
Fruits & $8 \pm 2 \mathrm{a}$ & $4 \pm 1 \mathrm{~b}$ \\
Flowers (catkins) & $13 \pm 4$ & $17 \pm 7$ \\
Other & $3 \pm 1$ & $2 \pm 0.6$ \\
Total litter fall & $261 \pm 18 \mathrm{a}$ & $211 \pm 23 \mathrm{~b}$ \\
\hline
\end{tabular}

from the higher $\Psi_{\text {pd }}$ and low $\Psi_{\text {md }}$, maintaining the stomatal conductance in accordance to the exhibited higher productivities.

\subsection{Tree litterfall and phenological development}

Leaves and branches were the main components of litter fall, representing on average 72 and $18 \%$ of total litter fall in both years. However, the mean quantity of shed leaves and branches decreased about 20\% in 2012 compared to 2011 (Table 3). Fruits and catkins showed opposite trends in 2012: fruits decreased by $54 \%$ whereas catkins increased $28 \%$ although showing a higher variability among trees.

Budburst in 2011 started in mid-April (DOY 111), ca. 30 days earlier than in 2012 (Fig. 5). Catkins also developed earlier in 2011 than in 2012, concomitantly with leaf expansion period, although completing their development earlier and being all shed by DOY 137 and 158, respectively. Due to the later budburst in 2012 the completion of leaf expansion was also delayed until early summer (ca. DOY 187). Similarly, fruit fall started and ended later in 2012

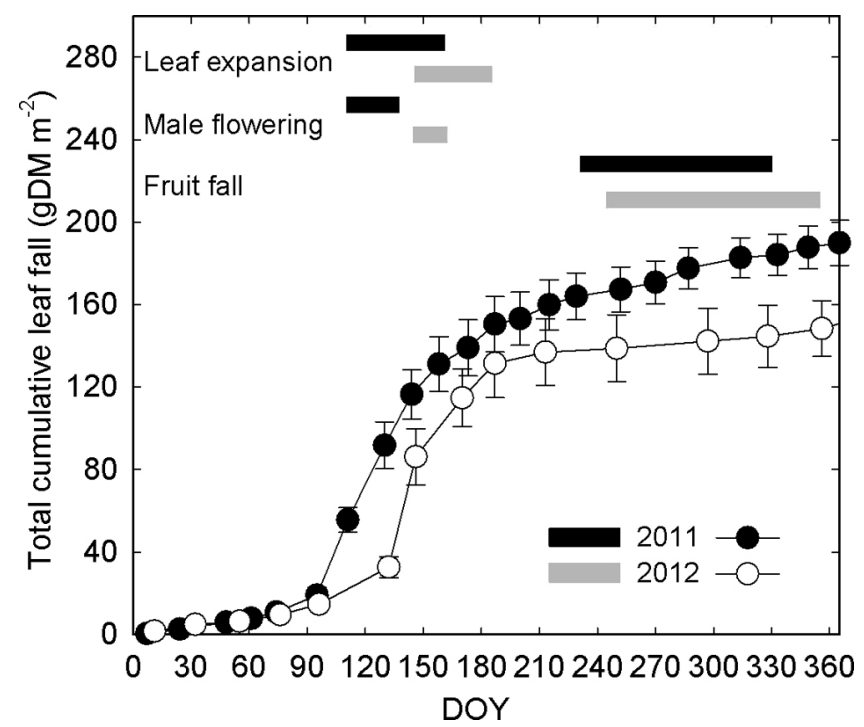

Fig. 5. Total cumulative leaf fall during 2011 and 2012 in $\mathrm{g} \mathrm{DM} \mathrm{m}^{-2}$ and time interval of different phenological stages. Values are means \pm se $(n=6)$.

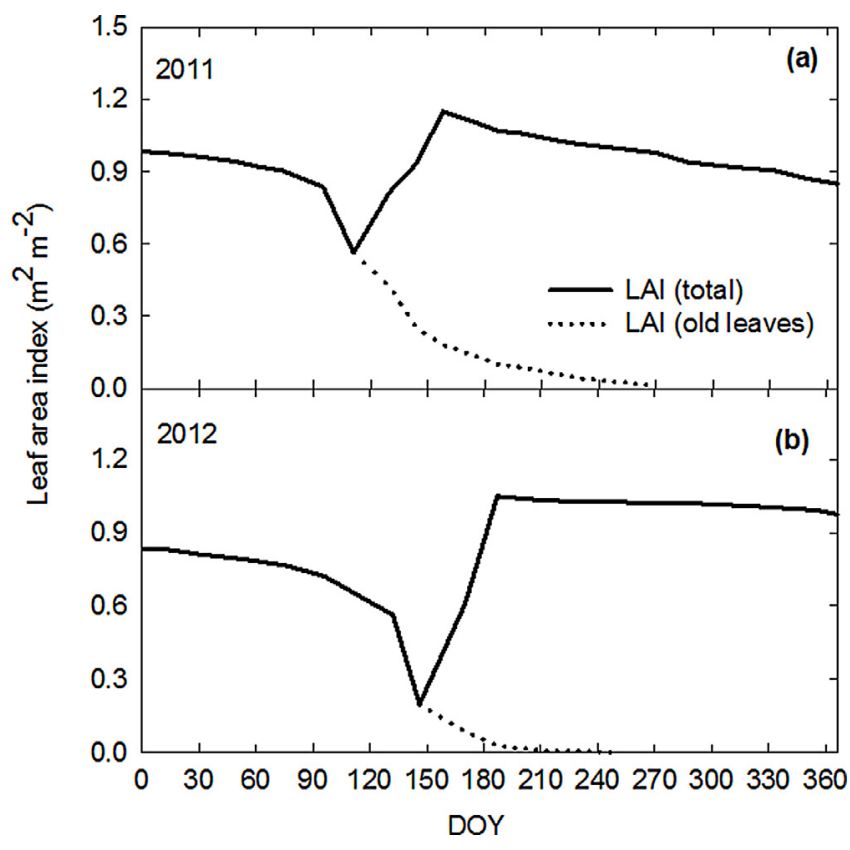

Fig. 6. Tree leaf area index (LAI) during 2011 (a) and 2012 (b). The dash line represents LAI of old leaves matured in the previous spring.

than in 2011. Leaf fall occurred mainly between DOY 95 and 187 in 2011 and 2012 ( 69 and $77 \%$ of total leaves shed, respectively). In both years the first period of leaf fall is the most intense with highest shedding rates. However, different patterns of leaf shedding can be evidenced between years. Leaf fall started earlier in 2011 than in 2012 (ca. DOY 95 vs. 132, respectively) although with a noteworthy higher intensity of leaf shedding in 2012 (2.3 vs. $3.8 \mathrm{~g} \mathrm{~m}^{-2} \mathrm{day}^{-1}$, respectively).

\subsection{Tree leaf area index}

Tree leaf area index (LAI) is in direct relation with leaf fall and new leaf growth during the spring (Fig. 6). The lower intensity of leaf fall during the spring of 2011 led to a smoother transition of old to new leaves in the canopy which is reflected in a higher minimum LAI in 2011 on DOY 111 when compared to the minimum LAI in 2012 on DOY 146 (0.56 vs. $0.2 \mathrm{~m}^{2} \mathrm{~m}^{-2}$, respectively). In addition, this period of canopy renewal and concomitantly low LAI is in accordance to a low carbon sequestration and lower values of LUE in both years (Figs. 2 and 4). Furthermore, due to the earlier canopy renewal in $2011, \mathrm{LAI}_{\max }$ was also reached earlier than in 2012 (ca.DOY 158 vs. 187, respectively) which extended the growing season in a favorable period of water availability. Due to the different leaf fall intensities between years the relative contribution of older leaves (matured in the previous spring) to each year LAI is also diverse. Therefore, in the early summer of 2011 old leaves contributed with $15.5 \%$ to LAI $_{\max }$ whereas in 2012 its contribution was restricted to $2.5 \%$. Nevertheless, in both years by DOY 270 all old leaves were shed. Despite greater leaf fall during 2011 than in 2012, $\mathrm{LAI}_{\max }$ was $9.5 \%$ higher with 1.15 and $1.05 \mathrm{~m}^{2} \mathrm{~m}^{-2}$, respectively.

\subsection{Tree diameter increment}

Tree diameter increment started earlier in 2011 than in 2012 (DOY 61 vs. 76, respectively) and with sustained higher daily increments throughout the growing season (Fig. 7). In fact, maximum diameter growth rates in 2011 were double of those in 2012 (ca. 2 vs. $1 \mathrm{~mm} \mathrm{month}^{-1}$, respectively). Furthermore, the duration of the growth period extended in 2011 till the end of the summer 


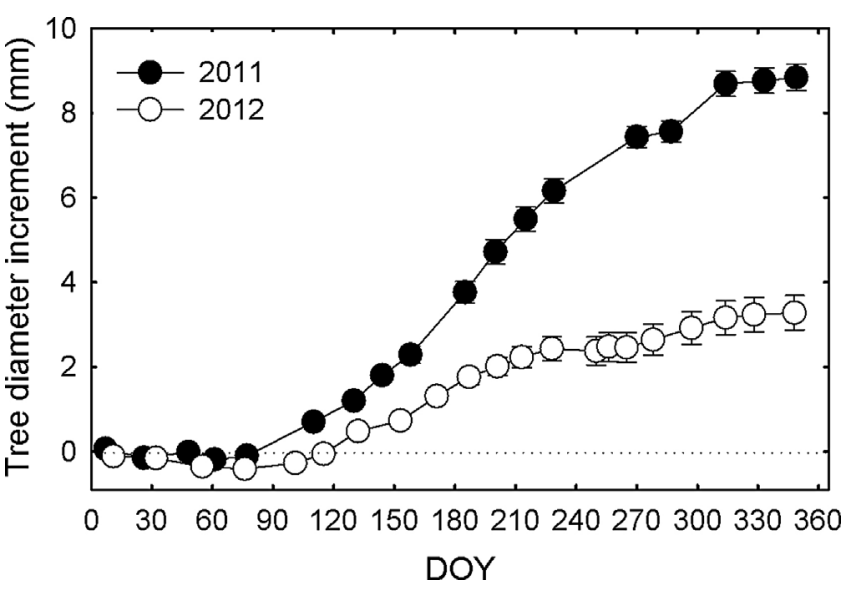

Fig. 7. Tree diameter increment (mm) during 2011 and 2012. Values are means \pm se $(n=9)$.

(DOY 270) whereas in 2012 tree diameter increment was inhibited by drought conditions in the middle of the summer even with a decrease in trunk diameter in the period DOY 228-250. Worth mentioning is the halt observed in tree diameter increment between DOY 127 and 156 in the spring of 2012 whereas in 2011 there were continuous growth increments. In addition, a large increse in 2011 was recorded after the first autumn rains in contrast to 2012. Overall, total annual diameter increment in 2012 decreased $63 \%$ compared to 2011 ( 8.8 vs. $3.3 \mathrm{~mm}$, respectively).

\section{Discussion}

\subsection{Ecosystem $\mathrm{CO}_{2}$ fluxes and seasonal patterns}

The values for our cork oak ecosystem carbon balance - with an average NEE of $-301 \mathrm{~g} \mathrm{C} \mathrm{m}^{-2}$ year $^{-1}$ - compare well with flux measures of carbon sequestration in related Mediterranean oak ecosystems. For example, a Quercus ilex forest in southern France showed an average NEE of $-278 \mathrm{~g} \mathrm{C} \mathrm{m}^{-2}$ year $^{-1}$ (Allard et al., 2008) and a closed canopy mature Quercus cerris forest in Central Italy $-288 \mathrm{~g} \mathrm{C} \mathrm{m}^{-2}$ year $^{-1}$ (Baldocchi et al., 2010). However, when comparing with savannah-like, open woodlands in a similar climatic region, this cork oak woodland showed higher productivities: a $Q$. ilex open woodland in southern Portugal presented $-87 \mathrm{~g} \mathrm{C} \mathrm{m}^{-2}$ year $^{-1}$ (Baldocchi et al., 2010). The main reasons for this higher productivity can be attributed to a higher LAI (1.1 vs. 0.5 , respectively) and to a higher soil water availability to the tree roots which is suggested by the much higher ET (397 $\mathrm{mm}$ year $^{-1}$, Table 1 ) in comparison to the low ET in the $Q$. ilex open woodland

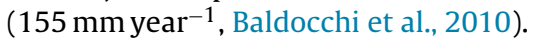

In this Mediterranean climate with marked seasonality the cork oak ecosystem showed a productivity peak in June and July. There was a time-lag between soil water availability and carbon sequestration, reflected in a prolonged productivity throughout summer which only significantly declined after an extreme dry winter as happened in 2012. As a result, a marked difference is observed in comparison to other Mediterranean, such as $Q$. ilex ecosystems, where more than $80 \%$ of the yearly NEE occurs between March and June and in summer becomes a source of carbon to the atmosphere (e.g., Allard et al., 2008; Pereira et al., 2007). Whereas in our site, regardless of the year, $48 \%$ of the total annual C sequestration occurred during this period with a further significant carbon sequestration in the summer months (44 and 26\% in 2011 and 2012, respectively). Thus, the high annual NEE in our cork oak woodland, with relatively low LAI, should be attributed to an extended length of the growing season through summer period linked both to higher soil water availabilities and most probably to the presence of a reachable water table (ca. $4-5 \mathrm{~m}$ deep) by the tree roots. A $Q$. ilex forest located in a site (Castelporziano, Italy) with low annual rainfall $(781 \mathrm{~mm})$ exhibited a NEE comprised between -547 and $-660 \mathrm{~g} \mathrm{C} \mathrm{m}^{-2}$ year $^{-1}$ (Tirone et al., 2003). This high NEE was explained by the presence of a shallow ground water table that reduces water limitation during the summer. Recently it was reported strong evidence that $Q$. suber trees use predominantly soil water during most of the year and groundwater in summer (performing hydraulic lift) when the surface soil is dry (David et al., 2013; Besson et al., 2014; Pinto et al., 2013). In addition, the fact that in both years the minimum daily GPP were registered in the autumn/winter days rather than in the summer (Fig. 3a and b) support that summer water stress was only partially limiting GPP.

Although changes in spring phenology exert a major influence on the carbon balance of temperate and boreal deciduous forests (e.g., Baldocchi et al., 2001; Baldocchi, 2008; Richardson et al., 2010) its effect in evergreen Mediterranean oaks is less evident since phenological changes are not clearly associated with a carbon source-sink transition. For example, Richardson et al. (2010) showed that productivity of evergreen needleleaf forests is less sensitive to phenology variability than deciduous broadleaf forests. However, among evergreen Mediterranean oak species Q. suber leaf habits are singular in that leaf life-span is generally short - ca. 12 (Oliveira et al., 1994; Pereira et al., 1987) to 15 months (Escudero and Mediavilla, 2003) - and leaf fall is highly concentrated in a short period of time (Caritat et al., 1996, 2006; Oliveira et al., 1994). These specific traits had a marked influence in the spring carbon balance of the studied cork oak woodland. Thus, in both years a clear carbon sequestration depression is associated to leaf canopy renewal where the ecosystem becomes a temporary carbon source (Fig. 3). This reduction in carbon sequestration in April 2011 and May 2012 represents on average a $15 \%$ reduction of yearly NEE. Two orders of reasons explain this fact: first, the noticeable transitory decrease in leaf area due to intense leaf fall which led to an average reduction of $49 \%$ in LAI (Fig. 6) and, second, a decoupling between tree canopy carbon uptake and respiration in this period. In fact, absolute GPP decreased and $R_{\text {eco }}$ increased in the most intense phase of leaf fall relatively to prior leaf fall onset (Fig. 3). This decoupling is expected both from carbohydrate and nitrogen translocation during leaf senescence associated with reduced photosynthetic capacity (Escudero and Mediavilla, 2003; Niinemets et al., 2005) and from a negative carbon balance in the emerging new leafs with incipient photosynthesis and high growth respiration costs (Dickson, 1989).

Q. suber growth may be limited in winter both by low temperatures (Aranda et al., 2005) and low incident radiation. In 2012 - where carbon sequestration in winter was $45 \%$ of yearly total (Fig. 3c) - a large increase in absolute NEE was observed by comparison to 2011 in response to a 57\% higher incident PAR, although air temperatures were similar in both years for this period (Fig. 1). Thus, and since precipitation was practically inexistent $(10 \mathrm{~mm})$, tree productivity in winter seems to be highly dependent on available incident radiation. This clearly puts into perspective the advantage of evergreeness in environments with relatively mild winters where air temperatures do not strongly limit carbon uptake. Leaf persistence allows a significant ecosystem productivity to be achieved outside of the most favorable growing period - spring to early summer - through an adjustment of growth to environmental resources availability (e.g., Baldocchi et al., 2010). This feature is particularly relevant under the highly variable Mediterranean climate and considering the actual susceptibility of the Mediterranean region to winter/spring climatic changes, namely in temperature and precipitation (e.g., Giorgi and Lionello, 2008). 


\subsection{Effects of extreme dry winter on $\mathrm{CO}_{2}$ fluxes}

The effect of a severe dry winter and a consequent low soil water refilling in 2012 led to a $45 \%$ decrease in annual carbon uptake in relation to 2011 , from -388 to $-214 \mathrm{~g} \mathrm{C} \mathrm{m}^{-2}$ year $^{-1}$, respectively. This decrease in absolute NEE for the cork oak woodland is similar to that reported for a $Q$. ilex forest (51\%, Allard et al., 2008) but lower than the $64 \%$ decrease found in a Q. ilex open woodland (Pereira et al., 2007) during years of severe drought. However, in this $Q$. ilex open woodland with a low tree crown cover (ca. 30\%) a large proportion of NEE was attributable to the carbon assimilated by its annual vegetation component, which was strongly affected by the shortage of rain in winter (Pereira et al., 2007).

The drought effects in 2012 carbon sequestration differed among seasons. Nevertheless, it was in summer that the ecosystem was more affected by the low water availability with reductions of $44 \%$ in ecosystem evapotranspiration (Table 1) and $66 \%$ in carbon sequestration relative to summer 2011. This lower net $C$ uptake during summer 2012 was the result of carbon assimilation being more hindered than ecosystem respiration due to drought (decreases of 46 and 33\%, respectively, relative to summer 2011). The summer drought stress in 2012 reflected in lower tree leaf water potentials (Table 2) and lower light use efficiency (Fig. 4). Even though $Q$. suber is considered a drought resilient tree well adapted to the adverse semiarid summer conditions (e.g., Pereira et al., 2009), a photosynthesis decrease usually occurs as the result of stomatal closure to regulate transpiration losses (e.g., Besson et al., 2014; Vaz et al., 2010) and photoinhibition (Werner and Correia, 1996). Even under the less-limited water supply conditions in 2011, stomata closure seems to have been still controlling transpiration losses, although later in the summer. This results from the evolutionary safety function of stomata to prevent leaf water potential to fall below a cavitation threshold (Buckley and Mott, 2002) that would lead to catastrophic damages in the root-leaf hydraulic pathway (Tyree and Sperry, 1988), i.e., losses in water transport capability. In both years the minimum leaf water potentials measured in the peak of summer water stress ( $\Psi_{\text {md }}$, Table 2$)$ were above the $-2.9 \mathrm{MPa}$ water potential threshold, which causes a $50 \%$ loss in hydraulic conductivity (50 PLC) due to embolism in Q. suber shoots (Pinto et al., 2012). Thus, by forfeiting summer carbon uptake due to the deep root system and an efficient stomatal control, cork oak trees succeeded in maintaining the minimum leaf water potential above the 50 PLC embolism threshold, throughout the experimental period. This also explains why leaf area index was relatively stable during the two years of observation. Vilagrosa et al. (2003) report that leaf dieback only occurs when stomata regulation is no longer effective, allowing PLC to rise and leaf water potential to drop (typically to around $-5 \mathrm{MPa}$ ). Nevertheless, in the summer drought stress period of 2012 the observed safety margins above the 50 PLC threshold were narrower and photosynthetic limitations higher, reflecting the general observed GPP reduction (Fig. 3b).

\subsection{Effects of extreme dry winter in tree growth and phenology}

Annual stem diameter growth decreased 63\% in 2012 compared to 2011 (Fig. 7). The seasonal reductions in tree diameter growth follow the same pattern as NEE in spring and summer. Thus, diameter growth reductions in 2012 relatively to 2011 were much higher in summer (76\%) than in spring (48\%). However, if summer growth impairment can be directly linked to the observed low soil water availabilities and photosynthetic limitations (as discussed above), in the wet spring the absence of tree water stress call for a further understanding. It has been shown that spring growth flush in evergreen trees depend both on currently fixed and stored carbohydrates from the previous seasons (Cerasoli et al., 2004; Dickson,
1989) and that those are closely involved in early xylem differentiation in Q. suber trees (Aguado et al., 2012). In our case we can dismiss the hypothesis of stored carbon differences between both years in early spring since previous growing conditions were similar or even more favorable during the winter 2012 (Fig. 3). More probably the decrease in stem diameter growth during spring 2012 can be ascribed to three orders of interconnected effects: (1) a shorter favorable growing season length due to a later budburst (ca. 30 days); (2) higher intensities of leaf fall and a consequent although temporary - much lower LAI and (3) a potential lower canopy nitrogen content (see below).

It has been reported that for Mediterranean oak species air temperature is the main environmental driver for budburst timing (e.g., Morin et al., 2010; Pinto et al., 2011; Sanz-Perez et al., 2009). Although thermal times and base temperatures could not be estimated from our data, the fact that the month of April preceding budburst date in 2011 exhibited an average air temperature $6^{\circ} \mathrm{C}$ higher than in April 2012 (Fig. 1) supports that air temperature increase was the main cause for the 30-day earlier budburst in 2011. The extent of this advance agrees with results from Sanz-Perez et al. (2009) where budburst occurred 6-10 days earlier per degree spring temperature increase. This high sensitivity of budburst to changing environmental conditions reflect a phenological plasticity that allow plants in drier zones to extend the growing period before summer drought (Bertero et al., 2000). The immediate consequence of an earlier budburst is the lengthening of the growing season allowing trees to reach maximum photosynthetic capability earlier in the most favorable stages of the growth season, i.e., late spring and early summer. It has been generally reported that longer growing seasons lead to higher net ecosystem carbon uptakes (e.g., Richardson et al., 2010) in the order of a further $3.7 \mathrm{~g} \mathrm{C} \mathrm{m}^{-2}$ per day in evergreen broadleaved forests and Mediterranean oak-grass savannah (Baldocchi, 2008).

Relative to 2011 a higher intensity of leaf shedding was observed in 2012 in the early spring. As a result, the minimum LAI in 2012 was 65\% lower than in 2011 (Fig. 6). This was reflected both in a steeper absolute NEE decrease (Fig. 3) and in a concomitant stem diameter growth stop in the same period (DOY 127-156, Fig. 7) in contrast to 2011 where stem diameter growth rates were sustained. This strongly suggests that stored and current carbon uptake were insufficient in spring 2012 for meeting growth sink demands and that new leaf expansion was a priority sink in contrast to diameter stem growth, in accordance to its much larger reduction when compared to LAI (48 vs. $9 \%$, respectively). Thus, assuring tree canopy renewal and maintaining a relatively stable LAI seems to be an ecological trait preserved even under extreme low winter precipitation and reflects $Q$. suber resilience to drought. Maintaining a threshold LAI in these Mediterranean type climates may allow cork oak ecosystems to optimize productivity under a water-availability uncertainty, relying in morphological traits (e.g., deep roots) and physiological responses (e.g., stomatal regulation) to face unpredictable seasonally water stresses. However, the magnitude and timings of drought events can have significant different LAI costs as was shown for an extreme spring drought in a $Q$. ilex forest occurring in parallel with leaf phenological development, leading to critical impacts impairing ca. 50\% of leaf unfolding (Misson et al., 2011).

Finally, we can speculate that during spring 2012 there was a lower canopy nitrogen content with a consequent lower carbon uptake capacity. This is plausible given the high intensity of leaf fall during the spring of 2012 indicating that sink organs were accelerating senescence rate in old leaves to satisfy their nitrogen demand. This was perhaps the result from low rates of nitrogen uptake in roots since low shallow soil water availability in spring (Fig. 2) may have led to low soil nutrient availability for surface roots (Ryel et al., 2010) in a soil with an a priori low nitrogen content (Table 1). This hypothesis is supported by Ono et al. (1996) showing that 
nitrogen deficiency in new organs changes with sink development and nitrogen uptake rates, and that the rate of leaf senescence is well correlated to nitrogen deficiency.

In contrast to male flower production fruit setting was highly depressed by water stress showing a reduction of $54 \%$ during the dry year of 2012 (Table 3). There is evidence that summer drought impairs fruit development through the abortion of immature acorns in Mediterranean oaks (e.g., Montserrat-Marti et al., 2009; Perez-Ramos et al., 2010). Female flower maturation and the following acorn growth occur from early summer up to early autumn (Misson et al., 2011; Oliveira et al., 1994) which makes these phenophases highly dependent on soil water availabilities and photoassimilates produced throughout summer. On the contrary, male flowers are produced in early spring - in synchrony with leaf expansion (Fig. 5) - although being considered to have low carbon costs and low sink priority compared to fruits and even to vegetative growth (Ho, 1992). This would explain a regular male flowering much less dependent on drought effects as it was observed in spring 2012. A similar result was reported by Misson et al. (2011) for Q. ilex under an extreme spring drought. Furthermore, in accordance to our results Penuelas et al. (2004) and Montserrat-Marti et al. (2009) showed that most of species including Quercus species - delayed flowering and fruit maturation during dry years.

\section{Conclusions}

In summary, cork oak woodland net ecosystem $\mathrm{CO}_{2}$ exchange and phenology adjustments were studied here for the first time. Among evergreen Mediterranean oak species $Q$. suber leaf habits are singular in so far as leaf life-span is short and leaf fall is highly concentrated in a short spring period. Leaf phenological events of canopy renewal are associated with an average $15 \%$ reduction of yearly carbon sequestration. Both, soil water availability and the extension of the favorable growing season in spring and early summer - as controlled by budburst date and leaf expansion period were equally determinant for the lower annual carbon sequestration in the dry year of 2012. Furthermore, our results suggest that new leaf growth in spring and maintenance of a relatively stable leaf area index are ecophysiological traits preserved even following an extreme dry winter. On the contrary, tree diameter growth is not a priority sink for photoassimilates. Thus, cork oak woodland reductions in carbon sequestration under low water availabilities are mainly due to stomatal or photosynthetic limitations and to a much lesser extent to leaf area reductions. The present work adds some new insights on how ecosystem carbon sequestration seasonality may interact with a changing phenology under climate change.

\section{Acknowledgements}

The authors acknowledge the financial support of Fundação para a Ciência e Tecnologia, through the postdoctoral fellowships to F. Costa-e-Silva (SFRH/BPD/46839/2008) and A. Correia (SFRH/BD/39058/2007). This work was supported by the projects "Cork carbon footprint: from trees to products (PTDC/AGRFOR/4360/2012)" and "Long-term socio-ecological research and monitoring in a Mediterranean cultural landscape - LTER Montado (LTER/BIA-BEC/0048/2009)". The authors wish to thank António Gonçalves Ferreira for providing field site facilities at Machoqueira do Grou and Grupo Amorim for continuous support in the eddyflux tower maintenance. We also thank the anonymous reviewers for the helpful and constructive comments on the manuscript.

\section{References}

Aguado, P.L., Dolores Curt, M., Pereira, H., Fernandez, J., 2012. Allocation of C-14 assimilated in late spring to tissue and biochemical stem components of cork oak (Quercus suber L.) over the seasons. Tree Physiol. 32 (3), 313-325.

Allard, V., Ourcival, J.M., Rambal, S., Joffre, R., Rocheteau, A., 2008. Seasonal and annual variation of carbon exchange in an evergreen Mediterranean forest in southern France. Global Change Biol. 14 (4), 714-725.

Allen, R.G., Pereira, L.S., Raes, D., Smith, M., 1998. Crop evapotranspiration: guidelines for computing crop requirements. In: Irrigation and Drainage Paper No. 56. FAO, Italy, 300 pp.

Aranda, I., Castro, L., Alia, R., Pardos, J.A., Gil, L., 2005. Low temperature during winter elicits differential responses among populations of the Mediterranean evergreen cork oak (Quercus suber). Tree Physiol. 25 (8), 1085-1090.

Aronson, J., Pereira, J.S., Pausas, J., 2009. Cork Oak Woodlands on the Edge: Ecology, Biogeography, and Restoration of an Ancient Mediterranean Ecosystem. Island Press, Washington, DC.

Aubinet, M., et al., 2000. Estimates of the annual net carbon and water exchange of forests: the EUROFLUX methodology. Adv. Ecol. Res. 30, 113-175.

Baldocchi, D., 2008. Breathing of the terrestrial biosphere: lessons learned from a global network of carbon dioxide flux measurement systems. Aust. J. Bot. 56 (1), 1-26.

Baldocchi, D., et al., 2001. FLUXNET: a new tool to study the temporal and spatial variability of ecosystem-scale carbon dioxide, water vapor, and energy flux densities. Bull. Am. Meteorol. Soc. 82 (11), 2415-2434.

Baldocchi, D., et al., 2010. On the differential advantages of evergreenness and deciduousness in mediterranean oak woodlands: a flux perspective. Ecol. Appl. 20 (6), 1583-1597.

Bertero, H.D., King, R.W., Hall, A.J., 2000. Photoperiod and temperature effects on the rate of leaf appearance in quinoa (Chenopodium quinoa). Aust. J. Plant Physiol. 27, 349-356.

Besson, C.K., et al., 2014. Cork oak physiological responses to manipulated water availability in a Mediterranean woodland. Agric. For. Meteorol. 184, 230-242.

Buckley, T.N., Mott, K.A., 2002. Stomatal water relations and the control of hydraulic supply and demand. Prog. Bot. 63 (63), 309-325.

Bugalho, M.N., Caldeira, M.C., Pereira, J.S., Aronson, J., Pausas, J.G., 2011. Mediterranean cork oak savannas require human use to sustain biodiversity and ecosystem services. Front. Ecol. Environ. 9 (5), 278-286.

Caritat, A., Bertoni, G., Molinas, M., Oliva, M., Dominguez-Planella, A., 1996. Litterfall and mineral return in two cork-oak forests in northeast Spain. Ann. Sci. For. 53 (6), 1049-1058.

Caritat, A., Garcia-Berthou, E., Lapena, R., Vilar, L., 2006. Litter production in a Quercus suber forest of Montseny (NE Spain) and its relationship to meteorological conditions. Ann. For. Sci. 63 (7), 791-800.

Cerasoli, S., et al., 2004. Carbon and nitrogen winter storage and remobilisation during seasonal flush growth in two-year-old cork oak (Quercus suber L.) saplings. Ann. For. Sci. 61 (7), 721-729.

Correia, A.C., et al., 2014. Carbon sink strength of a Mediterranean cork oak understorey: how do semi-deciduous and evergreen shrubs face summer drought? J. Veg. Sci. 25 (2), 411-426.

Costa, A., Pereira, H., Oliveira, A., 2003. Variability of radial growth in cork oak adult trees under cork production. For. Ecol. Manage. 175 (1-3), 239-246.

David, T.S., et al., 2007. Water-use strategies in two co-occurring Mediterranean evergreen oaks: surviving the summer drought. Tree Physiol. 27 (6), 793-803.

David, T.S., et al., 2013. Root functioning, tree water use and hydraulic redistribution in Quercus suber trees: a modeling approach based on root sap flow. For. Ecol. Manage. 307, 136-146.

Dickson, R.E., 1989. Carbon and nitrogen allocation in trees. Ann. Sci. For. 46, S631-S647.

Escudero, A., Mediavilla, S., 2003. Decline in photosynthetic nitrogen use efficiency with leaf age and nitrogen resorption as determinants of leaf life span. J. Ecol. 91 (5), 880-889.

Eugster, W., Senn, W., 1995. A Cospectral correction model for measurement of turbulent $\mathrm{NO}_{2}$ flux. Boundary-Layer Meteorol. 74 (4), 321-340.

Evangelista, M., 2010. Relatório da Caracterizacão da Fileira Florestal 2010. Associação Para a Competitividade da Indústria da Fileira Florestal, Portugal, 80 pp.

Foken, T., Wichura, B., 1996. Tools for quality assessment of surface-based flux measurements. Agric. For. Meteorol. 78 (1-2), 83-105.

Giorgi, F., Lionello, P., 2008. Climate change projections for the Mediterranean region. Global Planet. Change 63 (2-3), 90-104.

Ho, L.C., 1992. Fruit growth and sink strength. In: Marshall, C., Grace, J. (Eds.), Fruit and Seed Production. Aspects of Development, Environmental Physiology and Ecology. New York, Cambridge University Press, pp. 101-124.

Hollinger, D.Y., et al., 1994. Carbon-dioxide exchange between an undisturbed old-growth temperate forest and the atmosphere. Ecology 75 (1), 134-150.

Ibrom, A., Dellwik, E., Larsen, S.E., Pilegaard, K., 2007. On the use of the webb pearman-leuning theory for closed-path eddy correlation measurements. Tellus B 59 (5), 937-946.

IPCC, 2003. Good Practice Guidance for Land Use, Land-use Change and Forestry. Intergovernmental Panel on Climate Change - Section 3.2. Institute for Global Environmental Strategies (IGES) for the IPCC, Kanagawa, JP.

Kolle, O., Rebmann, C., 2007. Eddysoft - Documentation of a Software Package to Acquire and Process Eddy-covariance Data. Technical Reports. Max-Planck-Institute for Biogeochemistry 10, Jena, DE. 
Kurz-Besson, C., et al., 2006. Hydraulic lift in cork oak trees in a savannah-type Mediterranean ecosystem and its contribution to the local water balance. Plant Soil $282(1-2), 361-378$.

Limousin, J.M., et al., 2009. Long-term transpiration change with rainfall decline in a Mediterranean Quercus ilex forest. Global Change Biol. 15 (9), 2163-2175.

Mauder, M., Foken, T., 2011. Documentation and Instruction Manual of the Eddy-Covariance Software Package TK3. Universitt Bayreuth Abt. Mikrometeorologie.

Misson, L., et al., 2011. Phenological responses to extreme droughts in a Mediterranean forest. Global Change Biol. 17 (2), 1036-1048.

Montserrat-Marti, G., et al., 2009. Summer-drought constrains the phenology and growth of two coexisting Mediterranean oaks with contrasting leaf habit: implications for their persistence and reproduction. Trees-Struct. Funct. 23 (4), 787-799.

Morin, X., Roy, J., Sonie, L., Chuine, I., 2010. Changes in leaf phenology of three European oak species in response to experimental climate change. New Phytol. 186 (4), 900-910.

Neftel, A., Spirig, C., Ammann, C., 2008. Application and test of a simple tool for operational footprint evaluations. Environ. Pollut. 152 (3), 644-652.

Niinemets, U., Cescatti, A., Rodeghiero, M., Tosens, T., 2005. Leaf internal diffusion conductance limits photosynthesis more strongly in older leaves of Mediterranean evergreen broad-leaved species. Plant Cell Environ. 28 (12), 1552-1566.

Oliveira, G., Correia, O., Martinsloucao, M., Catarino, F.M., 1994. Phenological and growth-patterns of the Mediterranean oak Quercus suber L. Trees-Struct. Funct. 9 (1), 41-46.

Ono, K., Terashima, I., Watanabe, A., 1996. Interaction between nitrogen deficit of a plant and nitrogen content in the old leaves. Plant Cell Physiol. 37 (8), 1083-1089.

Otieno, D.O., et al., 2007. Regulation of transpirational water loss in Quercus suber trees in a Mediterranean-type ecosystem. Tree Physiol. 27 (8) 1179-1187.

Papale, D., et al., 2006. Towards a standardized processing of net ecosystem exchange measured with eddy covariance technique: algorithms and uncertainty estimation. Biogeosciences 3 (4), 571-583.

Paulo, J., Tomé, M., 2006. Equações Para Estimação do Volume e Biomassa de Duas Espécies de Carvalhos: Quercus suber e Quercus ilex. Publicações do GIMREF; RC1/2006. Instituto Superior de Agronomia, Departamento de Engenharia Florestal, Lisboa.

Penuelas, J., et al., 2004. Complex spatiotemporal phenological shifts as a response to rainfall changes. New Phytol. 161 (3), 837-846.

Pereira, J.S., Beyschlag, G., Lange, O.L., Beyschlag, W., Tenhunen, J.D., 1987. Comparative phenology of four Mediterranean shrub species growing in Portugal. In: Tenhunen, J.D., Catarino, F.M., Lange, O.L., Oechel, O.L. (Eds.), Plant Response to Stress. Springer-Verlag, Berlin, Heidelberg, pp. 503-512.

Pereira, J.S., Chaves, M.M., Caldeira, M.C., Correia, A.V., 2006. Water availability and productivity. In: Morrison, J.I.L., Morecroft, D. (Eds.), Plant Growth and Climate Change. Blackwell Publishers, London, pp. 118-145.

Pereira, J.S., Kurz-Besson, C., Chaves, M.M., 2009. Coping with drought. Part II. Scientific Bases for restoration and management. In: Aronson, J., Pereira, J.S., Pausas, J.G. (Eds.), Cork Oak Woodlands on the Edge: Ecology, Adaptive Management, and Restoration. Island Press, Washington, DC, pp. 73-80.

Pereira, J.S., et al., 2007. Net ecosystem carbon exchange in three contrasting Mediterranean ecosystems - the effect of drought. Biogeosciences 4 (5), 791-802.
Perez-Ramos, I.M., Ourcival, J.M., Limousin, J.M., Rambal, S., 2010. Mast seeding under increasing drought: results from a long-term data set and from a rainfall exclusion experiment. Ecology 91 (10), 3057-3068.

Pinto, C.A., et al., 2012. Drought-induced embolism in current-year shoots of two Mediterranean evergreen oaks. Forest Ecol. Manage. 285, 1-10.

Pinto, C.A., et al., 2011. Phenology and growth dynamics in Mediterranean evergreen oaks: effects of environmental conditions and water relations. Forest Ecol. Manage. 262 (3), 500-508.

Pinto, C.A., et al., 2013. Transpiration in Quercus suber trees under shallow water table conditions: the role of soil and groundwater. Hydrol. Processes 28 (25), 6067-6079.

Rebmann, C., et al., 2012. Data acquisition and flux calculations. In: Eddy Covariance: a Practical Guide to Measurement and Data Analysis. Springer, Dordrecht, pp. 59-84.

Reichstein, M., et al., 2013. Climate extremes and the carbon cycle. Nature 500 (7462), 287-295.

Reichstein, M., et al., 2005. On the separation of net ecosystem exchange into assimilation and ecosystem respiration: review and improved algorithm. Global Change Biol. 11 (9), 1424-1439.

Richardson, A.D., et al., 2010. Influence of spring and autumn phenological transitions on forest ecosystem productivity. Philos. Trans. R. Soc. B: Biol. Sci. 365 (1555), 3227-3246.

Richardson, A.D., et al., 2006. A multi-site analysis of random error in tower-based measurements of carbon and energy fluxes. Agric. For. Meteorol. $136(1-2)$ $1-18$.

Ryel, R.J., Leffler, A.J., Ivans, C., Peek, M.S., Caldwell, M.M., 2010. Functional differences in water-use patterns of contrasting life forms in Great Basin steppelands. Vadose Zone J. 9 (3), 548-560.

Sanz-Perez, V., Castro-Diez, P., Valladares, F., 2009. Differential and interactive effects of temperature and photoperiod on budburst and carbon reserves in two co-occurring Mediterranean oaks. Plant Biol. 11 (2), 142-151.

Schotanus, P., Nieuwstadt, F.T.M., Debruin, H.A.R., 1983. Temperature-measurement with a sonic anemometer and its application to heat and moisture fluxes. Boundary-Layer Meteorol. 26 (1), 81-93.

Thomas, C., Foken, T., Ams, A.M.S., 2002. Re-evaluation of integral turbulence characteristics and their parameterisations. 15th Symposium on Boundary Layers and Turbulence.

Tirone, G., Dore, S., Matteucci, G., Greco, S., Valentini, R., 2003. Evergreen Mediterranean forests. Carbon and water fluxes, balances, ecological and ecophysiological determinants. In: Valentini, R. (Ed.), Fluxes of Carbon, Water and Energy of European Forests. Ecological Studies. Springer Verlag, Berlin Heidelberg, pp. 126-149.

Tyree, M.T., Sperry, J.S., 1988. Do woody-plants operate near the point of catastrophic xylem dysfunction caused by dynamic water-stress - answers from a model. Plant Physiol. 88 (3), 574-580.

Vaz, M., et al., 2010. Drought-induced photosynthetic inhibition and autumn recovery in two Mediterranean oak species (Quercus ilex and Quercus suber). Tree Physiol. 30 (8), 946-956.

Vilagrosa, A., Bellot, J., Vallejo, V.R., Gil-Pelegrín, E., 2003. Cavitation, stomatal conductance, and leaf dieback in seedlings of two co-occurring Mediterranean shrubs during an intense drought. J. Experimen. Bot. 54, 2015-2024.

Werner, C., Correia, O., 1996. Photoinhibition in cork-oak leaves under stress: influence of the bark-stripping on the chlorophyll fluorescence emission in Quercus suber L. Trees-Struct. Funct. 10 (5), 288-292.

Wilczak, J.M., Oncley, S.P., Stage, S.A., 2001. Sonic anemometer tilt correction algorithms. Boundary-Layer Meteorol. 99 (1), 127-150. 